\title{
Kontekstualitas Makna "Bersamaan Kedudukan di Dalam Hukum dan Pemerintahan" Menurut Undang-Undang Dasar 1945
}

\author{
Hernadi Affandi* \\ DOI: https://doi.org/10.22304/pjih.v4n1.a2
}

\begin{abstract}
Abstrak
Rumusan Pasal 27 ayat (1) Undang-Undang Dasar 1945 masih menyisakan perbedaan pandangan dalam memaknai frasa "segala warga negara bersamaan kedudukannya di dalam hukum dan pemerintahan". Apakah frasa tersebut mengandung prinsip "persamaan kedudukan di depan hukum' atau dalam konteks yang berbeda. Pembahasan pasal tersebut dalam sidang Badan Penyelidik Usaha Persiapan Kemerdekaan Indonesia dan Panitia Persiapan Kemerdekaan Indonesia ternyata tidak terlalu signifikan dalam menjelaskan makna pasal. Tulisan ini akan menyoroti kontekstualisasi makna "bersamaan kedudukan di dalam hukum dan pemerintahan" menurut UUD 1945 yang akan difokuskan kepada tiga aspek, yaitu: pertama, latar belakang perumusan Pasal 27 ayat (1) UUD 1945 dalam sidang BPUPKI dan PPKI; kedua, makna bersamaan kedudukan di dalam hukum menurut UUD 1945; dan ketiga, hubungan antara bersamaan kedudukan di dalam hukum dan bersamaan kedudukan di dalam pemerintahan. Terhadap tiga hal tersebut Penulis berpendapat, pertama, perancang UUD tidak mau mengikuti pemikiran barat yang mengedepankan kebebasan dan sifat individualisme. Kedua, bersamaan kedudukan di dalam hukum menempatkan semua warga negara ke dalam kelompok atau golongan yang sama, tanpa pembedaan atas dasar apa pun seperti suku, agama, ras, dan antar-golongan. Ketiga semua warga negara memiliki hak dan kesempatan yang sama untuk mengelola negara sepanjang memenuhi persyaratan objektif.
\end{abstract}

Kata kunci: bersamaan kedudukan di dalam hukum dan pemerintahan, hak, kontekstualitas, undang-undang dasar, warga negara.

\section{Contextualization on The Meaning of "Equality Before the Law and Government" According to the 1945 Constitution}

\begin{abstract}
The formulation of Article 27 paragraph (1) of the 1945 Constitution still left a various perspectives on the meaning of the phrase "all citizens have equality before the law and government"; whether the article contains the principle of equality before the law or not. The Committee for Preparatory Work for Indonesia Independence/BPUPKI and Preparatory Committee for Indonesian Independence/PPKI sessions already delivered their views on all aspects related to the substance of the 1945 Constitution, however their views were not really clear. This article will discusses three main aspects, namely reviewing at the
\end{abstract}

PADJADJARAN Jurnal IImu Hukum Volume 4 Nomor 1 Tahun 2017 [ISSN 2460-1543] [e-ISSN 2442-9325]

Dosen Fakultas Hukum Universitas Padjadjaran, Jl. Dipati Ukur No. 35 Bandung, hernadi.affandi@unpad.ac.id, S.H. (Universitas Padjadjaran), LL.M. (Universiteit Utrecht), Dr. (Universitas Padjadjaran). 
background of the formulation of Article 27 paragraph (1) of the 1945 Constitution in BPUPKI and PPKI sessions; reviewing the equality before the law and government status under the 1945 Constitution; and reviewing the relationship between equality before the law and equality before the government. The Author concludes that first, the 1945 Constitution drafter did not want to follow western idea which highlight Freedom and individualism; second, equality before the law places all citizens in the same status without any discrimination based on race, religion, or class; and third, all citizens have the right to administer the state as long as they fulfill the objective requirement.

Keywords: equality before the law and government, right, contextualization, constitution, citizen.

\section{A. Pendahuluan}

Undang-Undang Dasar 1945 (UUD 1945) sudah berusia lebih dari 70 tahun sejak disahkan oleh Panitia Persiapan Kemerdekaan Indonesia (PPKI) pada tanggal 18 Agustus 1945. Dalam perjalanan sejarah ketatanegaraan Indonesia, UUD 1945 sempat tidak berlaku selama sepuluh tahun karena digantikan oleh Konstitusi Sementara Republik Indonesia Serikat (KSRIS 1949) dan Undang-Undang Dasar Sementara 1950 (UUDS 1950). UUD 1945 juga sudah mengalami perubahan sebanyak empat kali yaitu pada tahun 1999, 2000, 2001, dan 2002. ${ }^{1}$ Selama perjalanannya tersebut, UUD 1945 mengalami pasang dan surut sebagai dasar hukum dalam penyelenggaraan berbagai aspek kehidupan bermasyarakat, berbangsa, bernegara, dan berpemerintahan di Indonesia.

Namun demikian, dalam tataran praktik dan teoretik perbedaan pandangan bahkan perdebatan secara konseptual masih sering terjadi dalam menyikapi materi muatan UUD 1945. Salah satunya berkaitan dengan makna rumusan Pasal 27 ayat (1) UUD 1945 yang berbunyi "Segala warga negara bersamaan kedudukannya di dalam hukum dan pemerintahan dan wajib menjunjung hukum dan pemerintahan itu dengan tidak ada kecualinya". Perbedaan pandangan yang terjadi antara lain menyangkut makna dalam rumusan Pasal 27 ayat (1) UUD 1945 sama atau tidak dengan prinsip persamaan kedudukan di depan hukum (prinsip PKDH) yaitu equality before the law atau equality under the law seperti halnya di negara-negara lain. ${ }^{2}$

Di satu pihak, ada pendapat yang menyatakan bahwa UUD 1945 dianggap mengatur dan menganut prinsip PKDH yang setara dengan prinsip equality before

1 Sekretariat Jenderal Majelis Permusyawaratan Rakyat Republik Indonesia (Sekjen MPR), Panduan Pemasyarakatan Undang-Undang Dasar Negara Republik Indonesia Tahun 1945, Cetakan ke-2, Jakarta: Sekretariat Jenderal MPR, 2006, hlm. 40.

2 Hernadi Affandi, "Menegaskan Hubungan Antara Prinsip Persamaan Kedudukan di Depan Hukum dengan Demokrasi dan Negara Hukum", dalam buku Negara Hukum yang Berkeadilan: Kumpulan Pemikiran Dalam Rangka Purnabakti Prof. Dr. H. Bagir Manan, S.H., MCL., yang disusun oleh Susi Dwi Harijanti (eds), Bandung: Rosda dan PSKN-FH Unpad, 2011, hlm. 556. 
the law atau equality under the law di negara-negara lain, seperti Inggris, Amerika Serikat, dan lain-lain. Dalam pandangan pihak pertama, hal itu menunjukkan bahwa secara konseptual prinsip PKDH dianggap sudah dianut dalam UUD 1945 sebagai landasan hukum tertinggi di Indonesia. ${ }^{3}$ Rumusan itu memang tidak sama persis menggunakan kata 'persamaan' tetapi menggunakan kata 'bersamaan'. Namun demikian, bagi pihak pertama rumusan Pasal 27 ayat (1) UUD 1945 dianggap mengandung prinsip PKDH.

Di lain pihak, pendapat yang menyatakan bahwa UUD 1945 justru dianggap tidak mengandung prinsip PKDH karena yang digunakan adalah kata 'bersamaan' dan bukan kata 'persamaan'. Alasan sederhana karena secara harfiah kata bersamaan berbeda dengan kata persamaan, sehingga maknanya juga dianggap berbeda satu sama lain. Dalam pandangan yang kedua tersebut, UUD 1945 sama sekali tidak mengandung prinsip PKDH seperti halnya di negara-negara lain. Hal itu disebabkan Pasal 27 ayat (1) UUD 1945 tidak menyatakan secara tegas tentang prinsip PKDH tersebut. Perbedaan pandangan tersebut terus terjadi dalam mengartikan dan memaknai rumusan Pasal 27 ayat (1) UUD 1945 tersebut.

Secara kebetulan atau tidak, rumusan Pasal 27 ayat (1) UUD 1945 tersebut tidak mengalami perubahan pada waktu terjadi perubahan UUD 1945 mulai dari perubahan pertama sampai dengan keempat. Akibat tidak ada perubahan terhadap rumusan Pasal 27 ayat (1) UUD 1945, muncul anggapan bahwa rumusan tersebut dianggap benar baik dari segi konsep maupun teknis bahasa hukum. Padahal bahasa Indonesia sudah mengalami perkembangan seiring dengan kemajuan dan perkembangan zaman, sehingga sangat mungkin terjadi perubahan makna dari awal perumusannya. Oleh karena itu, makna dari rumusan itu perlu disesuaikan dengan konteksnya agar dapat mengikuti perubahan dan perkembangan zaman. Dengan kata lain, perlu dilakukan kontekstualisasi rumusan itu sesuai dengan situasi kekinian atau masa yang akan datang.

Perbedaan pandangan terhadap rumusan Pasal 27 ayat (1) UUD 1945 bermula dari digunakannya kata 'bersamaan' dan bukan kata 'persamaan'. Dalam perspektif bahasa hukum sebenarnya apa makna kata 'bersamaan' itu, apakah sama atau berbeda dengan kata 'persamaan'. Oleh karena itu, pengertian tersebut perlu dikaji agar memperoleh kejelasan, sekaligus untuk menemukan makna tersebut sebagaimana diinginkan oleh pembentuk UUD 1945. Selain itu, diskursus yang juga masih muncul berkaitan dengan hakikat bersamaan kedudukan di dalam hukum dan pemerintahan dalam tataran pelaksanaannya. Dalam hal ini apakah bersamaan kedudukan di dalam hukum akan menjamin adanya pengakuan bersamaan

$3 \quad$ Hernadi Affandi, “Penerapan Prinsip Persamaan Kedudukan di Depan Hukum Terhadap Hak Warga Negara Untuk Turut-Serta Dalam Pemerintahan Berdasarkan Undang-Undang Dasar 1945”, Disertasi, Bandung: Program Studi Doktor Ilmu Hukum Fakultas Hukum Universitas Padjadjaran, 2013, hlm. 7. 
kedudukan di dalam pemerintahan. Untuk itu, perlu dilihat hubungan antara bersamaan kedudukan di dalam hukum dan bersamaan kedudukan di dalam pemerintahan khususnya dalam alam Indonesia yang sudah merdeka.

Berkaitan dengan permasalahan di atas, tulisan ini akan difokuskan kepada 3 (tiga) hal, yaitu: pertama, melihat latar belakang perumusan Pasal 27 ayat (1) UUD 1945 dalam sidang Badan Penyelidik Usaha-Usaha Persiapan Kemerdekaan Indonesia (BPUPKI) dan PPKI; kedua, melihat makna bersamaan kedudukan di dalam hukum dan pemerintahan menurut UUD 1945; ketiga, melihat hubungan antara bersamaan kedudukan di dalam hukum dan bersamaan kedudukan di dalam pemerintahan, apakah hanya dalam konteks persyaratan menjadi presiden?

\section{B. Latar Belakang Perumusan Pasal 27 ayat (1) UUD 1945 Dalam Sidang Badan Penyelidik Usaha Persiapan Kemerdekaan Indonesia dan Panitia Persiapan Kemerdekaan Indonesia}

Sejak disahkannya UUD 1945 oleh PPKI, rumusan Pasal 27 ayat (1) UUD 1945 sudah dianggap final dan mengikat secara hukum terlepas dari kata atau istilah yang digunakannya tepat atau tidak tepat, lengkap atau tidak lengkap, salah atau tidak salah, dan sebagainya. Apapun kekurangan yang dimiliki oleh UUD 1945 tetap mengikat sampai dilakukan perubahan atau penambahan terhadap ketentuan tersebut. Demikian pula halnya, rumusan Pasal 27 ayat (1) meskipun dianggap masih menimbulkan multi-tafsir, secara normatif sudah mengikat dan tetap berlaku apa adanya. Perbedaan pandangan dalam memaknai materi muatan UUD 1945, termasuk Pasal 27 ayat (1), adalah dalam upaya menggali pemahaman lebih dalam dari sisi akademik-ilmiah.

Perbedaan pandangan terhadap makna yang terkandung dalam Pasal 27 ayat (1) UUD 1945 masih berlangsung terus sampai sekarang terutama di kalangan akademisi. Dalam menjawab perbedaan pandangan atau perdebatan terkait dengan makna atau kandungan pasal-pasal dalam UUD 1945 biasanya merujuk kepada sejarah penyusunan dan perumusan UUD 1945. Seperti diketahui, penyusunan dan perumusan UUD 1945 dilakukan oleh BPUPKI, sedangkan pengesahan UUD 1945 dilakukan oleh PPKI. Demikian pula halnya, perdebatan seputar makna Pasal 27 ayat (1) UUD 1945 perlu dikaji dari sejarah yang terjadi pada saat sidang-sidang BPUPKI dan PPKI tersebut.

Pembentukan BPUPKI pada awalnya sebagai upaya persiapan akan diberikannya kemerdekaan atau dimerdekakannya Indonesia oleh Jepang yang diucapkan oleh Koiso pada awal September $1944 .{ }^{4}$ Selanjutnya, pada bulan Mei

4 Muhammad Hatta, Menuju Gerbang Kemerdekaan Untuk Negeriku Sebuah Otobiografi, Buku 3, Cetakan ke-7, Jakarta: PT. Kompas Media Nusantara, 2016, hlm. 64. Istilah yang digunakan oleh Muhammad Hatta berbeda dengan istilah yang digunakan oleh Muhammad Yamin. Muhammad Hatta menyebutnya Panitia, sedangkan 
1945 diadakan suatu badan atau panitia dengan nama BPUPKI atau Panitia Penyelidik Usaha-usaha Persiapan Kemerdekaan Indonesia. ${ }^{5}$ Selanjutnya BPUPKI dibubarkan dan digantikan dengan PPKI. Apabila dilihat dari perannya, kedua badan atau panitia tersebut amat berbeda tetapi memiliki hubungan yang erat. Menurut Saafroedin Bahar, peran BPUPKI adalah untuk mengkaji dan menelaah, sedangkan peran PPKI adalah untuk mengambil keputusan. ${ }^{6}$ Sebagai konsekuensi perbedaan peran tersebut, pembicaraan di dalam sidang BPUPKI masih bersifat gagasan atau ide yang masih terbuka untuk didiskusikan atau diperdebatkan.

Berkaitan dengan hal itu, Saafroedin Bahar memberikan catatan tentang perbedaan peran di antara kedua badan atau panitia tersebut sebagai berikut: ${ }^{7}$

"Pendapat-pendapat yang diajukan dalam BPUPKI merupakan prasaran yang ditawarkan untuk dibahas dan ditanggapi, dan oleh karena itu terbuka untuk diubah oleh para anggota lainnya. Sifatnya masih teoretikal. Di dalamnya kita temukan elaborasi yang mendalam terhadap filsafat kenegaraan dan hak warga negara serta penduduk. Pendalaman terhadap pembicaraan dalam BPUPKI penting untuk memahami latar belakang pikiran para pendiri negara." (Cetak tebal oleh Penulis)

Selanjutnya, Saafroedin Bahar menjelaskan peran PPKI yang berbeda dari peran BPUPKI sebagai berikut: ${ }^{8}$

"Sebaliknya, pendapat-pendapat yang diajukan dalam PPKI merupakan negosiasi dalam proses pengambilan keputusan dalam proses mendirikan negara, sehingga tidak banyak lagi ditemukan elaborasi. Sifat pembicaraan bersifat final, tinjauannya tidak lagi bersifat teoretikal, tetapi sudah bercorak politis dan legal." (Cetak tebal oleh Penulis)

Menurut Bagir Manan, rapat-rapat BPUPKI berpusat pada 3 (tiga) hal, yaitu: pertama, menemukan dasar atau landasan Indonesia merdeka; kedua, merumuskan rancangan pembukaan hukum dasar atau Preambul); dan ketiga, merumuskan rancangan UUD. ${ }^{9}$ Perjalanan sidang-sidang BPUPKI dimulai sejak tanggal 29 Mei 1945 sampai dengan 17 Juli 1945 yang terbagi ke dalam beberapa masa sidang termasuk masa reses. Sidang pertama dilaksanakan tanggal 29 Mei-1

Muhammad Yamin menyebutnya Badan. Secara umum, istilah yang digunakan adalah Badan, sehingga biasa disebut dengan BPUPKI.

$5 \quad$ lbid., hlm. 67.

6 Saafroedin Bahar dan Nannie Hudawati (eds), Risalah Sidang Badan Penyelidik Usaha-usaha Persiapan Kemerdekaan Indonesia (BPUPKI)-Panitia Persiapan Kemerdekaan Indonesia (PPKI), Edisi ke-IV, Cetakan ke-1, Jakarta: Sekretariat Negara Republik Indonesia, 1998, hlm. xx.

$7 \quad$ Ibid.

$8 \quad$ Ibid.

9 Bagir Manan, Membedah UUD 1945, Malang: UB Press, 2012, hlm. 17-18. 
Juni 1945, Reses 2 Juni-9 Juli 1945, dan Sidang kedua 10-17 Juli 1945. ${ }^{10}$ Menurut catatan dalam empat hari pertama ini telah berbicara 32 orang anggota BPUPKI, yaitu 11 orang pada tanggal $29 \mathrm{Mei}, 10$ orang pada tanggal $30 \mathrm{Mei}, 6$ orang pada tanggal 31 Mei, dan 5 orang pada tanggal 1 Juni 1945. ${ }^{11}$

Sementara itu, masa sidang kedua BPUPKI berlangsung mulai tanggal 10 sampai dengan 17 Juli 1945. Masa sidang kedua ini mempunyai arti penting dalam membahas dan mematangkan persiapan kemerdekaan Indonesia karena di dalamnya membahas mengenai dasar negara, serta tiga unsur negara, yaitu wilayah negara, warga negara, serta pemerintahan negara. ${ }^{12}$ Pembahasan mengenai rancangan UUD berlangsung pada masa sidang ini sampai menghasilkan rancangan UUD yang kemudian disahkan oleh PPKI pada tanggal 18 Agustus 1945. Dengan demikian, meskipun PPKI merupakan sebagian dari para anggota BPUPKI, hasil pekerjaannya amat berbeda di mana BPUPKI lebih kepada aspek persiapan, sedangkan PPKI lebih kepada persoalan konkret berupa pengambilan keputusan.

Berkaitan dengan keberadaan PPKI yang menggantikan BPUPKI, Muhammad Hatta menjelaskan bahwa: ${ }^{13}$

“Kira-kira permulaan Agustus 1945, Panitia Penyelidik Usaha-usaha

Persiapan Kemerdekaan Indonesia dibubarkan dan diganti dengan

Panitia Persiapan Kemerdekaan Indonesia di bawah pimpinan Sukarno sebagai ketua, Muhammad Hatta sebagai wakil ketua. Anggotanya diangkat dari seluruh Indonesia, sembilan orang dari Jawa dan 12 orang dari daerah-daerah luar Jawa. Mereka itu dipandang sebagai wakil seluruh Indonesia." (Cetak miring oleh Penulis)

Pembahasan rancangan UUD dalam BPUPKI dimulai tanggal 11 Juli 1945 dengan agenda utama antara lain persiapan penyusunan rancangan UUD dan pembentukan Panitia Perancang UUD. Panitia Perancang UUD diketuai oleh Soekarno, sedangkan Soepomo menjadi Panitia Perancang Hukum Dasar atau Panitia Pembentuk UUD Negara. Rancangan UUD hasil Tim Kecil di bawah Soepomo awalnya terdiri dari 42 pasal tanpa pembagian bab dan judul bab. Pembagian ke dalam bab-bab dan judul bab dengan nomor (angka) Romawi dilakukan atas usulan anggota Soesanto pada rapat Panitia Perancang UUD tanggal 13 Juli 1945 . $^{14}$

Dalam rapat tanggal 15 Juli 1945, Soepomo selaku ketua Panitia Perancang Hukum Dasar menyampaikan hasil kerja tim di hadapan sidang BPUPKI. Pada kesempatan tersebut Soepomo antara lain menjelaskan sebagai berikut: ${ }^{15}$

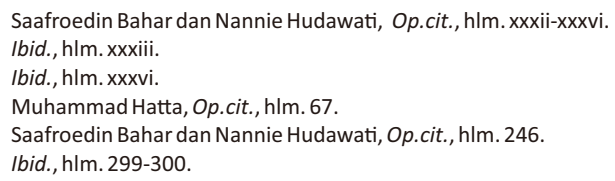




\begin{abstract}
"Sebabnya 'grondrechten' tidak dimasukkan dalam Undang-Undang Dasar, tadi dengan panjang lebar telah diuraikan oleh Tuan Ir. Soekarno. Sebagai penambahan keterangan saya hendak memajukan pemandangan sedikit. Bahwasannya Undang-undang Dasar negerinegeri Amerika dan Eropa menjamin hak-hak dasar rakyat itu, memang ada sebab-sebabnya, berhubung dengan riwayat negeri-negeri itu. Di dalam konstitusi Amerika dianggap perlu diadakan jaminan tadi, terutama jaminan kemerdekaan agama, oleh karena pada waktu membikin Undang-undang Dasar itu ada aliran untuk memaksa orang seseorang memeluk agama yang dijadikan oleh Raja Inggris (Raja Stuart) itu, kaum 'puritein' menganggap perlu menjamin kemerdekaan orang seseorang untuk memeluk agama apapun."
\end{abstract}

Pada bagian selanjutnya, Soepomo menjelaskan konsep paham kekeluargaan dalam konteks penyelenggaraan negara dan pemerintahan. Dalam kesempatan itu, Soepomo menegaskan bahwa: ${ }^{16}$

“Paduka Tuan Ketua, sebagai tadi telah saya katakan, Undang-undang Dasar yang kami rancangkan, berdasar atas faham kekeluargaan, tidak berdasar atas faham perseorangan, yang telah kita tolak. Pernyataan hak berkumpul dan berserikat di dalam Undang-undang Dasar adalah sistematik dari faham perseorangan, oleh karena itu dengan menyatakan hak bersidang dan berserikat di dalam Undang-undang Dasar kita akan menantang sistematik faham kekeluargaan."

Berkaitan dengan pandangan Soepomo tersebut, Soediman Kartohadiprodjo menyatakan bahwa: ${ }^{17}$

"Kata-kata ini diucapkan sebagai jawaban atas pertanyaan apa sebabnya dalam rancangan hukum dasar yang disusun oleh Panitia Sukarno berdasarkan Panca Sila yang baru diterima sebelumnya pada tanggal 1 Juni itu, tidak memuat apa yang orang sebut 'hak-hak asasi manusia', 'human rights', 'rights of citizens', 'droit de l'homme et du citoyen'. Karena apa yang dipertahankan itu adalah Panca Sila ini kemudian menjadi dasar negara kita, maka dapat diambil kesimpulan, bahwa Panca Sila menolak paham individualisme; suatu paham yang disandarkan pemikiran itu tadi, ialah "men are created free and equal." (Cetak tebal oleh Penulis).

16 Ibid., hlm. 300.

17 Soediman Kartohadiprodjo, "Pancasila Suatu Usaha Percobaan Mendekati Problema Sekitarnya", dalam buku Filsafat IImu Hukum yang disusun oleh B. Arief Sidharta, Bandung: Laboratorium Hukum Fakultas Hukum Universitas Katolik Parahyangan, 2005, hlm. 34. 
Dalam rancangan UUD tersebut Pasal 27 ayat (1) semula merupakan Pasal 28 ayat (1) dengan rumusan yang agak berbeda dengan rumusan setelah dibahas. Dalam rancangan awal, Pasal 28 ayat (1) yang kemudian menjadi Pasal 27 ayat (1) berbunyi: "Segala warga negara bersamaan kedudukannya di dalam hukum dan pemerintahan dan wajib menjunjung hukum dan pemerintahan itu, tidak ada terkecualinya". Rumusan tersebut kemudian diubah menjadi "Segala warga negara bersamaan kedudukannya di dalam hukum dan pemerintahan dan wajib menjunjung hukum dan pemerintahan itu dengan tidak ada kecualinya." Dalam hal ini, terjadi sedikit perubahan di mana frasa "tidak ada terkecualinya" diubah menjadi “tidak ada kecualinya" ditambah atau didahului kata'dengan'.

Selain itu, dalam rancangan UUD hasil Panitia Perancang Hukum Dasar (UUD) tidak dilakukan pembagian ke dalam bab-bab, meskipun terdapat 'judul atau kepala' untuk bagian-bagian tertentu. Berdasarkan jumlahnya, pasal-pasal yang mengatur warga negara sebanyak dua buah yaitu Pasal 27 dan Pasal 28. Kedua pasal tersebut berada pada bagian yang berbeda di mana Pasal 27 di bawah judul TENTANG WARGA NEGARA, sedangkan Pasal 28 berada di bawah judul TENTANG KEDUDUKAN WARGA NEGARA. Kedua pasal tersebut isinya lebih banyak melihat keberadaan warga negara dibandingkan dengan hak-hak yang dimiliki oleh warga negara. Dengan kata lain, pasal-pasal tersebut tidak secara khusus berbicara tentang hak-hak asasi manusia maupun hak-hak warga negara, tetapi mengatur tentang warga negara dan kedudukan warga negara. Setelah disahkan, Pasal 26 sampai dengan Pasal 28 dikelompokkan ke dalam Bab X (tentang) Warga Negara, sehingga Pasal 28 yang kemudian menjadi Pasal 27 tersebut masuk ke dalam bab tersebut.

Pembicaraan tentang Pasal 27 yang mengatur warga negara dan kedudukan warga negara dalam sidang BPUPKI masa kedua tersebut tidak terlalu banyak. Satusatunya pendapat dari anggota BPUPKI terkait dengan rumusan Pasal 27 dikemukakan oleh Soekardjo Wirjopranoto yang dikemukakan dalam sidang lanjutan BPUPKI tanggal 15 Juli 1945. Namun demikian, pendapat Soekardjo Wirjopranoto tersebut juga bukan dalam konteks mengomentari rumusan Pasal 27 secara langsung, tetapi dalam kaitannya mengomentari Pasal 26 tentang warga negara. Adapun komentar atau tanggapan Soekardjo Wirjopranoto terhadap rumusan Pasal 27 ayat (1) adalah dalam rangka menanggapi usul anggota lain yang bernama Haji Masjkoer.

Pada kesempatan itu, Haji Masjkoer mengajukan usul terkait dengan agama yang dianut oleh Presiden di satu sisi dan kewajiban menjalankan syariat Islam bagi pemeluk-pemeluknya di sisi lain sebagaimana diatur dalam Pasal 7 dan Pasal $28 .^{18}$

18 Rumusan Pasal 7 Rancangan Undang-Undang Dasar (Rancangan UUD) berbunyi: "Sebelumnya memangku jabatannya, Presiden dan Wakil Presiden bersumpah menurut agamanya, atau berjanji sungguh-sungguh di hadapan Badan Permusyawaratan Rakyat atau Badan Perwakilan Rakyat sebagai berikut: ..."; Sementara itu, 
Menurut Haji Masjkoer terjadi pertentangan di antara dua pasal tersebut. Adapun penggalan pandangan Haji Masjkoer sebagai berikut: ${ }^{19}$

“... Yang saya maksud ialah tentang apa yang tersebut di dalam Undang-undang Dasar, bahwa dalam Republik Indonesia adalah kewajiban menjalankan syariat Islam bagi pemeluk-pemeluknya. Lalu saya membaca di dalam rancangan Undang-undang Dasar ini ialah yang terdapat di dalam pasal 7, bahwa Presiden harus bersumpah menurut agamanya. Di situ nyata terang, bahwa Presiden itu beragama apa saja boleh. Dengan demikian, maka saya pikir keadaan begini; kalau di dalam Republik Indonesia ada dikepalai oleh orang beragama lain daripada Islam, umpamanya: apakah keadaan itu dapat dijalankan dengan baik, atau apakah umumnya golongan Islam dapat menerimanya, dan apakah demikian itu tidak jahat? Inilah menurut faham kami dua perkara yang menjadi soal kita. Soal itu kalau dilangsungkan, menjalar menjadi pertentangan." (Cetak tebal oleh Penulis)

Pada bagian selanjutnya, Haji Masjkoer mengajukan usul untuk menyelesaikan persoalan di atas sebagai berikut: ${ }^{20}$

"Maka menurut faham kami 2 buah pasal yang bertentangan itu dengan gampang dapat diselesaikan; kalau mungkin begitu, maka kita sekalian dengan dasar itu menerimanya seikhlas-ikhlasnya. Di antara satu dari 2 pasal itu diberi sedikit perubahan. Pertama: kalau Presiden tidak ditentukan orang Islam, maka yang tertulis di dalam pasal 28, yang berbunyi "Wajib menjadikan syariat Islam kepada pemelukpemeluk" diganti saja dengan kalimat "Agama resmi bagi Republik Indonesia ialah agama Islam". Bahkan faham itu lebih ringan, karena tidak ditulis, bahwa ia memikul kewajiban, tetapi hanya mengakuinya sebagai halnya ia mengakui lain-lain agama. Tentang caranya, saya rasa lebih mudah, apabila dalam salah satu di antara dua pasal itu, diadakan perubahan ialah ditentukan dalam pasal 7, bahwa Presiden harus orang Islam atau ayat di dalam pasal 28 diganti."

Pasal 28 Rancangan UUD yang dirujuk oleh Haji Masjkoer adalah yang kemudian menjadi Pasal 27 yang berbunyi: "Segala warga negara bersamaan kedudukannya di dalam hukum dan pemerintahan dan wajib menjunjung hukum dan pemerintahan itu, tidak ada terkecualinya". Namun demikian, jika dilihat dari kutipan yang disampaikan oleh Haji Masjkoer kalimat atau frasa yang dimaksud tidak ada. Demikian pula dalam Pasal 29 kalimat atau frasa tersebut tidak ditemukan. Pasal 29 hanya berisi satu ayat yang berbunyi: "Negara menjamin kemerdekaan tiap-tiap penduduk untuk memeluk agama apapun dan untuk beribadah menurut agamanya masing-masing". Oleh karena itu, rumusan Pasal 28 yang diusulkan untuk diubah tidak ditemukan dalam Rancangan UUD hasil Tim Soepomo.

19 Saafroedin Bahar dan Nannie Hudawati, Op.cit., hlm. 369.

20 Ibid. 
Berkaitan dengan usulan Haji Masjkoer tersebut, Soekardjo Wirjopranoto menyampaikan pandangannya sebagai berikut: ${ }^{21}$

"Saya mau berbicara tentang usul dari Tuan Haji Masjkoer yang belum puas. Tuan Ketua yang terhormat, apa yang saya kemukakan ialah satu keadilan yang saya percaya akan diterima dan dihormati oleh segenap rakyat, apa pun agamanya, keadilan itu tercantum seterang-terangnya, seindah-indahnya dalam Pasal 27. Saya baca:

"Segala warga negara bersamaan kedudukannya di dalam hukum dan pemerintahan". Artinya tiap-tiap warga negara mempunyai hak yang sama di dalam penghidupannya yang sudah tentu diperlindungi oleh hukum dan oleh pemerintah. Pendek kata, di dalam Negara Indonesia tidak akan ada kelas-kelas, kelas-kelas warga negara. Artinya tidak akan ada warga negara kelas 1, warga negara kelas 2, inilah keadilan. Konsekuensinya daripada keadilan itu ialah, bahwa tiap-tiap putra Indonesia berhak juga untuk menempati kedudukan Presiden Republik Indonesia." (Cetak tebal oleh Penulis)

Berkaitan dengan hal tersebut, Soekardjo Wirjopranoto juga mengingatkan agar tidak terjadi pembatasan atau hambatan bagi warga negara untuk menjadi Presiden karena alasan tertentu. Lebih lanjut, Soekardjo Wirjopranoto menyatakan bahwa: ${ }^{22}$ "Janganlah sebelumnya sudah diadakan suatu pagar, bahwa putera Indonesia yang bukan orang beragama Islam, meskipun ia bijaksana, meskipun ia tinggi budinya, meskipun ia pandai, meskipun ia giat, tidak bisa ia akan menduduki kedudukan Presiden Indonesia, hanya oleh karena ia tidak beragama Islam. Ini saya kuatirkan, kalau usul Kiai Haji Masjkoer itu diterima. Saya mengerti, saya menghargai usul atau pikiran Haji Masjkoer, tetapi saya juga harus mempertahankan keadilan yang sudah tentu akan mendapat perlindungan dari agama Islam. Inilah Tuan Ketua, yang saya kuatkan berhubung dengan pasal 27." (Cetak tebal oleh Penulis)

Menurut Sri Soemantri, setelah mengalami suana yang 'panas' dalam tiga hari sidang, yaitu tanggal 14 Juli sampai dengan 16 Juli 1945, Ketua BPUPKI menyatakan bahwa Naskah Rancangan Undang-Undang Dasar dengan perubahanperubahannya diterima sebulat-bulatnya oleh sidang. ${ }^{23}$ Selanjutnya, naskah rancangan UUD tersebut dibahas kembali dalam sidang PPKI yang berlangsung pada tanggal 18 Agustus 1945. Dalam sidang PPKI pun terjadi lagi perubahan terhadap

21 Ibid., hlm. 372-373. Lihat pula Hernadi Affandi, "Penerapan ..., Op.cit., hlm. 299-300.

22 lbid.

23 Sri Soemantri, Prosedur dan Sistem Perubahan Konstitusi, edisi Ke-2, Cetakan ke-1, Bandung: PT Alumni, 2006, hlm. 37-38. 
pasal-pasal tertentu termasuk penggunaan istilah dan penempatan bab, pasal, dan ayat. Dalam sidang PPKI itu pula rumusan Pasal 27 ayat (1) disepakati menjadi "Segala warga negara bersamaan kedudukannya di dalam hukum dan pemerintahan dan wajib menjunjung hukum dan pemerintahan itu dengan tidak ada kecualinya."

Berdasarkan uraian dan pandangan dari beberapa anggota BPUPKI dan PPKI di atas dapat diketahui bahwa berkaitan dengan rumusan Prinsip PKDH dalam UUD 1945, menurut Penulis ternyata UUD 1945 tidak mengaturnya secara eksplisit. Apabila diteliti, tidak ada satu pun rumusan pasal atau ayat dalam UUD 1945 yang secara tegas menyatakan tentang keberadaan Prinsip PKDH. Adapun Prinsip PKDH lebih didasarkan kepada hasil penafsiran terhadap bunyi Pasal 27 ayat (1)." ${ }^{24}$ Atas dasar frasa bersamaan kedudukan di dalam hukum dan pemerintahan itu ditafsirkan bahwa Pasal 27 ayat (1) UUD 1945 mengandung prinsip PKDH seperti halnya di negara-negara lain yang disebut equality before the law atau equality under the law.

Patut disayangkan bahwa pembicaraan atau perdebatan seputar rumusan Pasal 27 ayat (1) tidak cukup menjelaskan secara rinci tentang makna bersamaan kedudukan di dalam hukum dan pemerintahan. Ketiadaan risalah menyangkut alasan dan latar belakang rumusan yang kemudian menjadi Pasal 27 UUD 1945, menurut Penulis ditimbulkan oleh beberapa kemungkinan, yaitu: ${ }^{25}$

1. Tim Perancang tidak mau mengikuti alam pikiran Barat yang mengedepankan kebebasan dan sifat individualisme.

2. Anggota PPKI tidak terlalu mempersoalkan draft rumusan Pasal 27 yang dihasilkan oleh Panitia Kecil Tim Perancang.

3. Rumusan tersebut sudah dianggap dimengerti dan diterima oleh seluruh anggota PPKI, sehingga langsung disetujui.

4. Rumusan pasal tersebut tidak dipersoalkan karena secara umum masalah HAM sudah disepakati.

5. Rumusan pasal tersebut diterima untuk menegaskan pasal-pasal lain yang terkait dengan penduduk dan warga negara, khususnya Pasal 26.

\section{Makna Bersamaan Kedudukan di dalam Hukum dan Pemerintahan Menurut Undang-Undang Dasar 1945}

Rumusan final Pasal 27 ayat (1) hasil perumusan para pembentuk UUD 1945 adalah "Segala warga negara bersamaan kedudukannya di dalam hukum dan pemerintahan dan wajib menjunjung hukum dan pemerintahan itu dengan tidak ada kecualinya." Apabila rumusan Pasal 27 ayat (1) UUD 1945 diperhatikan, terdapat beberapa aspek yang terkandung di dalamnya. Menurut Penulis, hal itu

24 Hernadi Affandi, “Penerapan ..., Op.cit., hlm. 295.

25 Ibid., hlm. 295-296. 
dapat dilihat dari beberapa penggalan rumusan tersebut, yakni:

1. Segala warga negara bersamaan kedudukannya di dalam hukum;

2. (Segala warga negara bersamaan kedudukannya di dalam) pemerintahan;

3. (Segala warga negara) wajib menjunjung hukum;

4. (Segala warga negara wajib menjunjung) pemerintahan; dan

5. (Segala warga negara wajib menjunjung hukum dan pemerintahan) dengan tidak ada kecualinya.

Fokus subjek pengaturan dari Pasal 27 ayat (1) UUD 1945 adalah 'segala warga negara'. Secara leksikal, kata 'segala' memiliki banyak arti, yaitu: 1. semua, sekalian (tidak ada kecualinya); 2. seluruh, segenap; 3. sama sekali, serba; 4. Para (untuk menyatakan banyak; 5 . terlalu, benar-benar. ${ }^{26}$ Berdasarkan beberapa arti kata segala tersebut, kata segala dalam rumusan Pasal 27 ayat (1) lebih dekat kepada pengertian: semua, seluruh, atau segenap. Kata segala digunakan dalam merujuk kepada keseluruhan bukan pada bagian-bagian. Dengan demikian, secara teknis segala warga negara artinya adalah semua, seluruh, atau segenap warga negara. Dalam hal ini, frasa segala warga negara merujuk kepada keseluruhan warga negara dan bukan pada individu warga negara.

Selain dalam Pasal 27 ayat (1), kata segala terdapat pula dalam pasal-pasal lain UUD 1945, bahkan kata segala juga terdapat dalam Pembukaan UUD 1945. Secara umum, kata segala dipakai dalam kalimat atau frasa di bawah ini:

1. Kemerdekaan itu ialah hak segala bangsa (Pembukaan UUD 1945 alinea 1).

2. Segala putusan Majelis Permusyawaratan Rakyat ditetapkan dengan suara yang terbanyak (Pasal 2 ayat (3).

3. Menjalankan segala undang-undang dan peraturannya (Pasal 9, sumpah atau janji Presiden dan Wakil Presiden).

4. Segala pajak untuk keperluan negara berdasarkan undang-undang (Pasal 23 ayat (2)).

5. Segala badan negara dan peraturan yang ada masih langsung berlaku (Pasal II Aturan Peralihan).

6. Segala kekuasaannya dijalankan oleh Presiden dengan bantuan sebuah komite nasional. (Pasal IV Aturan Peralihan).

7. Presiden Indonesia mengatur dan menyelenggarakan segala hal yang ditetapkan dalam Undang-Undang Dasar ini. (Aturan Tambahan ayat (1)).

Sementara itu secara leksikal, kata 'bersamaan' artinya bersama-sama (dengan) atau berbareng (dengan). ${ }^{27}$ Dengan demikian, secara sederhana dapat diartikan bahwa penekanan kata 'bersamaan' tersebut bukan dalam rangka 'mempersamakan' segala warga negara di dalam hukum dan pemerintahan, tetapi 'menempatkan' segala warga negara tersebut bersama-sama di dalam hukum dan

26 W.J.S. Poerwadarminta, Kamus Umum Bahasa Indonesia, Jakarta: Pradnja Paramita, 1982, hlm. 885.

27 Ibid., hlm. 857. 
pemerintahan. Dengan kata lain, kata 'bersamaan' bukan dalam arti 'mengakui persamaan' (kedudukan), tetapi dalam upaya 'penempatan' segala warga negara ke dalam 'tempat yang sama', yaitu di depan atau di dalam 'hukum dan pemerintahan'. Tampaknya akan lebih jelas jika istilah yang digunakan dalam UUD 1945 tersebut adalah 'berkedudukan sama di dalam hukum dan pemerintahan' atau 'berkedudukan sama di depan hukum dan pemerintahan' ${ }^{28}$

Seperti sudah dijelaskan di atas bahwa rumusan "Segala warga negara bersamaan kedudukannya di dalam hukum dan pemerintahan" dalam Pasal 27 diartikan dalam konteks perlindungan yang diberikan oleh hukum dan pemerintah. Perlindungan yang dilakukan tersebut dalam bentuk tidak adanya pembedaan atau pemisahan warga negara ke dalam kelas-kelas yang dilakukan oleh hukum dan pemerintah. Dengan rumusan tersebut menunjukkan tidak ada pengelompokan warga negara ke dalam kelas-kelas karena secara hukum semua warga negara berada dalam kelas yang sama. ${ }^{29}$

Rumusan Pasal 27 ayat (1) UUD 1945 khususnya penegasan segala warga negara bersamaan kedudukan di dalam hukum adalah dalam upaya menghilangkan pengelompokan warga negara ke dalam kelompok atau kelas-kelas seperti halnya pada masa penjajahan Belanda. Seperti diketahui, pada masa Hindia Belanda terdapat penggolongan penduduk berdasarkan Regeringsreglement 1854 dan dilanjutkan dengan Indische Staatsregeling 1925. Selain itu, badan peradilan dan lembaga kejaksaan pada masa Hindia Belanda juga berbeda untuk golongan penduduk yang berbeda. Hal itu menunjukkan bahwa penduduk Indonesia pada waktu itu tidak "bersamaan kedudukan di dalam hukum". Hal itu yang kemudian mempengaruhi upaya menempatkan segala warga negara dalam kedudukan yang sama di dalam hukum.

Sejarah menunjukkan bahwa pada masa penjajahan Belanda, warga negara Hindia Belanda digolongkan ke dalam beberapa golongan rakyat berdasarkan perbedaan kebudayaan asal. ${ }^{30}$ Adapun golongan rakyat itu terdiri dari golongan rakyat Indonesia asli, golongan rakyat Timur Asing, dan golongan rakyat Eropa. ${ }^{31}$ Perbedaan hukum yang berlaku untuk masing-masing golongan itu terutama di bidang hukum privat dapat dikelompokkan ke dalam tiga golongan, yaitu: ${ }^{32}$

a. Golongan hukum adat;

b. Golongan hukum Eropa (Barat); dan

c. Golongan hukum Timur Asing.

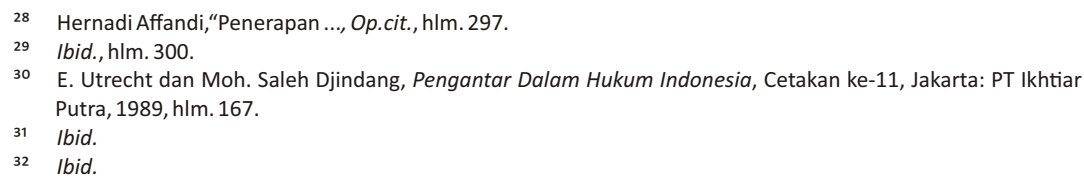


Berkaitan dengan rumusan Pasal 27 UUD 1945, menurut Utrecht kebudayaan asal masing-masing berbeda, sehingga dengan sendirinya sebagian dari hukum yang berlaku bagi masing-masing golongan rakyat itu masih belum sama. ${ }^{33}$ Perbedaan golongan tersebut tidak disebabkan karena persoalan agama di mana meskipun seseorang warga negara Indonesia asli maupun Timur asing beragama Kristen tidak serta-merta masuk ke dalam golongan hukum Eropa. Dalam hal ini, agama Kristen tidak menyebabkan seseorang Indonesia asli atau seseorang Timur Asing termasuk golongan Hukum Eropa. ${ }^{34}$

Keinginan para perumus dan penyusun UUD untuk menghilangkan penggolongan penduduk dan warga negara dan menempatkan pada kedudukan yang sama baru terwujud dalam kesempatan sidang-sidang BPUPKI dan PPKI. Menurut Daniel S. Lev, tatkala bala tentara Jepang menyerbu pada tahun 1942, para pemimpin Indonesia masih tetap menyimpan gagasan unifikasi dalam pikiran mereka, dan unifikasi itu terlaksana secara sempurna pada masa pendudukan (Jepang, Penulis). ${ }^{35}$ Hal itu tampak lebih nyata pada saat penyusunan UUD 1945 oleh BPUPKI dan PPKI sebagaimana dijelaskan di atas.

Senada dengan pendapat Daniel S. Lev di atas, Soetandyo Wignjosoebroto menyatakan bahwa: ${ }^{36}$

“Demikianlah kenyataannya, anno 1942, penduduk Hindia Belanda tetap dibedakan menjadi 3 golongan: Eropa, Pribumi, dan Timur Asing (Cina dan Timur Asing lain bukan Cina). Yang ipso jure terbilang golongan Eropa ternyata bukan saja orang-orang Belanda dan orangorang yang berasal dari Eropa berikut anak keturunannya (yang sah maupun yang diakui) saja, akan tetapi orang-orang Jepang dan orangorang lain yang di negeri asalnya juga dikenai hukum keluarga yang serupa atau seasas dengan hukum keluarga menurut hukum Belanda (seperti orang-orang Thai dan orang-orang Turki)."

Adanya penggolongan penduduk di atas menjadi bahan penting dalam perumusan Pasal 27 ayat (1) UUD 1945. Secara konseptual rumusan Pasal 27 ayat (1) UUD 1945 ditujukan untuk menghapus penggolongan tersebut. Dalam konsepsi Pasal 27 ayat (1) semua warga negara dianggap sama, sehingga ditempatkan dalam kedudukan yang sama di dalam hukum. Dalam konteks Pasal 27 ayat (1) semua warga negara tidak ada perbedaan yang disebabkan oleh perbedaan golongan penduduk seperti masa Hindia Belanda. Dengan kata lain, tujuan penempatan

33 Ibid.

34 Ibid., hlm. 168.

35 Daniel S Lev, Hukum dan Politik di Indonesia Kesinambungan dan Perubahan, buku diterjemahkan oleh Nirwono dan A.E. Prijono, Cetakan ke-3, Jakarta: LP3ES, 2013, hlm. 235.

36 Sutandyo Wignjosoebroto, Dari Hukum Kolonial ke Hukum Nasional Dinamika Sosial-Politik dalam Perkembangan Hukum di Indonesia, Cetakan ke-1, Jakarta: PT RajaGrafindo Persada, 1994, hlm. 177-178. 
segala warga negara dalam kedudukan yang sama di dalam hukum adalah untuk menjamin keadilan bagi semua warga negara tanpa kecuali.

Penolakan terhadap penggolongan penduduk seperti pada masa Hindia Belanda juga berkorelasi dengan upaya menghapuskan badan peradilan yang berbeda-beda. Pada masa Hindia Belanda masing-masing golongan penduduk tersebut memiliki pranata hukum dan pengadilan yang berlaku khusus untuk masing-masing golongan penduduk. Hal ini pula yang dianggap sebagai alasan pendorong untuk membuat segala warga negara bersamaan di dalam hukum khususnya dalam lembaga atau badan peradilan. Dengan demikian, setelah semua penduduk dimasukkan ke dalam satu golongan yang sama, yaitu warga negara Indonesia, badan peradilan yang berlaku juga sama. Hal itu sebenarnya diawali pada masa penjajahan Jepang tahun 1942-1945 yang menghapuskan dualisme badan peradilan di Indonesia. Namun demikian, alasan penghapusan dualisme badan peradilan oleh Jepang pasti berbeda dengan alasan yang diharapkan oleh para pendiri negara.

Berkaitan dengan upaya menghapuskan dualisme badan peradilan pada masa Jepang, Sutandyo Wignjosoebroto menyatakan bahwa: ${ }^{37}$

"Kontribusi paling penting yang diberikan oleh Jepang kepada sistem hukum Indonesia adalah dihapuskannya dualisme dalam tata peradilan. Kini hanya ada satu sistem peradilan saja untuk semua golongan penduduk (kecuali untuk orang-orang Jepang). Badan pengadilan tertinggi adalah Hooggerechtsschof yang kini disebut Saiko Hoin, dan kemudian berturut-turut adalah Raad van Justitie (Koto Hoin), Landraad (Tiho Hoin), dan Districtsgerecht (Gun Hoin). Residentiegerecht, yang pada masa kekuasaan Hindia Belanda mempunyai yurisdikasi khusus untuk mengadili perkara orang-orang Eropa saja, kini dihapus."

Mohammad Hatta selaku mantan anggota BPUPKI dan PPKI yang kemudian menjadi Ketua Panitia Lima ternyata menggunakan rumusan yang berbeda dari Pasal 27 UUD 1945 bahwa "Pasal 27: persamaan kedudukan dalam hukum dan pemerintahan, serta hak atas pekerjaan dan penghidupan yang layak bagi kemanusiaan." ${ }^{38}$ Berdasarkan rumusan yang dikemukakan oleh Muhammad Hatta tersebut, ternyata rumusan dalam Pasal 27 ayat (1) UUD 1945 yang berbunyi "Segala warga negara bersamaan kedudukannya di dalam hukum dan pemerintahan ..." diartikan sebagai "persamaan kedudukan dalam hukum dan pemerintahan ...". Dengan demikian, Mohammad Hatta sebagai salah seorang anggota BPUPKI dan PPKI menganggap bahwa Pasal 27 ayat (1) berisi tentang

37 Ibid., hlm. 177-184.

38 Mohammad Hatta (et.al.), Uraian Pancasila, Jakarta: Mutiara, 1978, hlm. 53. 
prinsip PKDH. Namun demikian, patut disayangkan bahwa pendapat Hatta tersebut tidak muncul pada waktu penyusunan UUD 1945 dalam sidang BPUPKI pada waktu itu. ${ }^{39}$

Senada dengan Muhammad Hatta, Bagir Manan bahkan menyatakan bahwa Pasal 27 mengandung atau memuat beberapa asas, di antaranya adalah asas persamaan kedudukan dalam (di depan) hukum atau lazim disebut 'equality before the $l a w^{\prime},{ }^{40}$ dan asas persamaan kedudukan di dalam (di depan) pemerintahan. ${ }^{41}$ Pendapat Bagir Manan tersebut tampaknya didasarkan kepada frasa "bersamaan kedudukan di dalam hukum dan pemerintahan" yang disamakan dengan pengertian "persamaan kedudukan di dalam hukum dan pemerintahan". Dengan demikian, baik Muhammad Hatta maupun Bagir Manan menganggap bahwa Pasal 27 UUD 1945 mengandung asas atau prinsip PKDH.

Menurut Bagir Manan, di bidang hukum persamaan meliputi baik hukum substantif maupun hukum acara. ${ }^{42}$ Persamaan di depan hukum itu harus diartikan terjadi baik dari sisi substansi hukum maupun penerapannya di pengadilan. Materi muatan atau hukum tertentu tidak boleh berisi atau bersifat diskriminatif yaitu membeda-bedakan karena alasan yang bertentangan dengan prinsip PKDH. Perbedaan dimungkinkan sepanjang perbedaan untuk memberi manfaat dan perlindungan terhadap mereka yang dibedakan, bukan untuk memencilkan atau mengucilkan mereka yang dibedakan.$^{43}$ Dengan demikian, bersamaan kedudukan di dalam hukum menurut UUD 1945 selain menempatkan warga negara pada kedudukan yang sama, juga sekaligus memberlakukan hukum yang sama terhadap warga negara yang berbeda.

Di lain pihak, Rukmana Amanwinata berpendapat bahwa Pasal 27 selain mengatur hak warga negara juga menentukan kewajiban warga negara. ${ }^{44}$ Pada bagian selanjutnya, Rukmana Amanwinata menegaskan bahwa hak asasi warga negara yang termuat dalam Pasal 27 ayat (1) berkaitan dengan 'kedudukannya dalam hukum' dan 'kedudukannya dalam pemerintahan'. ${ }^{45}$ Dengan demikian, secara tidak langsung Rukmana Amanwinata mengakui bahwa Pasal 27 ayat (1) mengandung Prinsip PKDH. Bahkan, secara khusus Rukmana Amanwinata mengaitkan prinsip PKDH dengan kedudukan warga negara dalam hukum dan pemerintahan. ${ }^{46}$

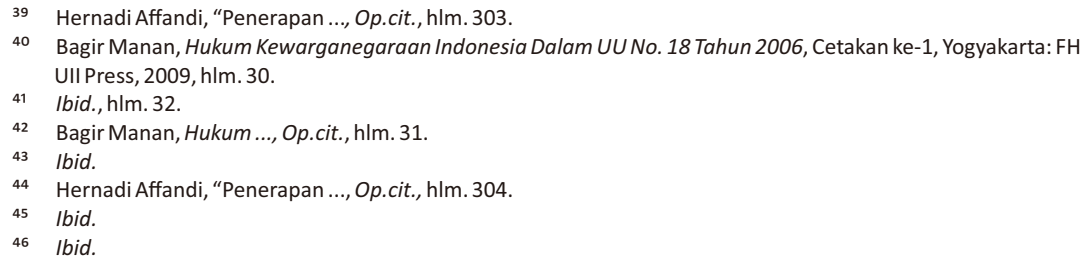


Dalam konteks Indonesia merdeka, bersamaan kedudukan di dalam hukum bukan hanya menempatkan semua warga negara ke dalam kelompok atau golongan yang sama, tetapi juga tidak ada pembedaan warga negara atas dasar apa pun seperti suku, agama, ras, dan antar-golongan (SARA). Demikian pula, kebersamaan warga negara tidak boleh terganggu karena perbedaan latar belakang sosial, budaya, ekonomi, profesi, jenis kelamin, dan lain-lain. Dengan kata lain, bersamaan kedudukan di dalam hukum pada alam Indonesia merdeka adalah pengakuan yang seluas-luasnya terhadap semua warga negara tanpa perbedaan apa pun. Konsekuensi pengakuan tersebut akan membawa kedudukan warga negara Indonesia siapa pun dan apa pun latar belakangnya akan memperoleh kesempatan yang sama di dalam pemerintahan. Dalam hal ini, segala jabatan dan profesi harus terbuka bagi semua warga negara yang memenuhi syarat tanpa memandang SARA, maupun latar belakang sosial, ekonomi, budaya, jenis kelamin, dan sebagainya.

\section{Hubungan antara Bersamaan Kedudukan di dalam Hukum dan Bersamaan Kedudukan dalam Pemerintahan}

Pasal 27 ayat (1) UUD 1945 tidak menegaskan adanya "bersamaan kedudukan di dalam" pemerintahan, tetapi secara substantif pasal tersebut mengandung dua pengertian yaitu bersamaan di dalam hukum dan bersamaan di dalam pemerintahan. Hal itu dapat dilihat dari penggunaan kata 'dan' setelah frasa di dalam hukum. Secara kebahasaan, penggunaan kata dan adalah untuk menghemat frasa yang semestinya sama, tetapi tidak digunakan berulang. Oleh karena itu, penggunaan kata dan secara substantif merujuk kepada frasa 'bersamaan di dalam', sehingga harus dibaca 'bersamaan di dalam hukum' dan 'bersamaan di dalam pemerintahan'. Dengan demikian, penggunaan bersamaan itu baik untuk di dalam hukum maupun di dalam pemerintahan.

Berkaitan dengan rumusan Paal 27 ayat (1) UUD 1945, Bagir Manan mengajukan pertanyaan: apakah benar ketentuan Pasal 27 merupakan hak dan kewajiban ekslusif (exclusive right and duty) yang hanya dilekatkan kepada warga negara. Apakah Pasal 27 semestinya berlaku untuk setiap orang yang berada dalam wilayah negara Republik Indonesia? Selain itu, muncul pertanyaan selanjutnya yaitu apa makna bersamaan kedudukan dalam pemerintahan dan apakah bersamaan kedudukan di dalam pemerintahan itu sama artinya dengan bersamaan di dalam hukum seperti dijelaskan di atas atau justru berbeda. Selain itu, apakah ada hubungan antara bersamaan di dalam pemerintahan dengan bersamaan di dalam hukum. Berkaitan dengan frasa bersamaan kedudukan di dalam pemerintahan, Bagir Manan menyebutnya sebagai asas persamaan kedudukan di dalam (di depan) pemerintahan. ${ }^{47}$ Dalam hal ini, Bagir Manan menegaskan bahwa asas ini

47 Bagir Manan, Hukum ..., Op.cit., hlm. 32. 
mengandung dua aspek, yaitu pertama: persamaan kesempatan bekerja atau menduduki jabatan pemerintahan. Kedua, berhak memperoleh perlakuan yang sama dari pemerintah. ${ }^{48}$ Dalam hal ini, Penulis juga dapat menambahkan bahwa bersamaan kedudukan dalam pemerintahan dapat dimaknai sebagai kesempatan untuk mengelola pemerintahan. Artinya, warga negara bersamaan kedudukan dalam pemerintahan karena warga negara adalah pemilik negara secara bersamasama.

Namun demikian, muncul pertanyaan dalam hal ini, yaitu apakah semua warga negara benar-benar berkedudukan sama dalam pemerintahan, artinya semua warga negara dapat turut bekerja, menduduki, atau mengelola negara? Apabila diilihat warga negara sendiri ada beberapa golongan berdasarkan asalnya, yaitu ada yang sejak kelahiran, tetapi ada juga yang karena proses pewarganegaraan (naturalisasi). Dalam hal ini, apakah benar semua warga negara apa pun latar belakang kewarganegaraannya benar-benar dapat memperoleh jabatan dalam negara? Berkaitan dengan hal itu tampaknya masih ada kendala dalam arti perlakuan itu menjadi tidak sama dan sebangun untuk semua warga negara untuk semua jabatan.

Apabila dilihat dari sejarah kewarganegaraan sebagaimana dijelaskan sebelumnya tampak bahwa di Indonesia pernah dan masih terdapat berbagai suku atau keturunan dari suku atau bangsa lain, seperti Belanda, Portugis, Tiongkok, Arab, dan sebagainya. Dalam hal ini, semua keturunan bangsa-bangsa tersebut yang saat ini sudah menjadi bagian dari warga negara Indonesia harus dijamin dan dibuka kesempatannya untuk memperoleh, menduduki, atau mengelola negara. Hal ini sebagai konsekuensi dari segala warga negara bersamaan kedudukan di dalam pemerintahan.

Secara praktis, bersamaan kedudukan dalam pemerintahan dapat diartikan sebagai terbukanya kesempatan yang sama untuk turut serta dalam pemerintahan. Dengan kata lain, hak warga negara untuk turut-serta dalam pemerintahan berarti dibukanya kesempatan yang sama kepada semua warga negara untuk bekerja di bidang pemerintahan, menduduki jabatan pemerintahan, maupun memperoleh perlakuan dan pelayanan yang sama dari pemerintah. ${ }^{49}$ Namun demikian, dalam Pasal 27 ayat (1) sebenarnya juga terkandung suatu pengecualian dalam memperoleh jabatan Presiden, yaitu harus orang Indonesia asli.

Senada dengan pandangan di atas, Usep Ranawidjaja menyatakan bahwa persamaan derajat dan persamaan kedudukan di segala bidang itu menurut paham

48 Ibid.

49 Hernadi Affandi, "Jaminan Konstitusional Hak Warga Negara Untuk Turut Serta Dalam Pemerintahan Setelah Perubahan Undang-Undang Dasar 1945", dalam buku Satu Dasa Warsa Perubahan UUD 1945, yang disusun oleh Ali Abdurahman (eds), Bandung: Pusat Studi Kebijakan Negara (PSKN) Fakultas Hukum Universitas Padjadjaran, 2012, hlm. 181. 
Pancasila merupakan syarat mutlak untuk dapat dilaksanakannya persamaan hak di antara manusia untuk menentukan nasibnya sendiri di segala bidang. ${ }^{50}$ Atas dasar pemikiran tersebut tampak bahwa persamaan di dalam pemerintahan adalah adanya peluang dan kesempatan bagi semua warga negara untuk turut serta dalam pemerintahan.

Adanya hubungan antara bersamaan kedudukan dalam hukum dan bersamaan kedudukan dalam pemerintahan juga dikemukakan oleh Soekardjo Wirjopranoto seperti sudah dijelaskan di atas. Tujuan perlindungan tersebut adalah dalam rangka mewujudkan keadilan dan perlakuan yang sama terhadap semua warga negara Indonesia. ${ }^{51}$ Dalam hal ini, semua warga negara harus dianggap memiliki hak yang sama untuk memperoleh atau menduduki jabatan termasuk menjadi Presiden sepanjang memenuhi syarat kecakapan. Secara argumentum a contrario, hal itu berlaku bagi setiap orang Indonesia terlepas dari agamanya Islam atau bukan, selama memenuhi syarat bijaksana, tinggi budinya, pandai, dan giat. Dengan demikian, terdapat hubungan yang erat antara Prinsip PKDH yang menempatkan seluruh warga negara ke dalam kelas yang sama dengan kesempatan setiap warga negara untuk menduduki jabatan Presiden. ${ }^{52}$

Selain itu, pandangan Soekardjo Wirjopranoto dalam mengomentari Pasal 27 ayat (1) adalah bahwa yang berhak atau yang dapat menjadi Presiden adalah hanya laki-laki dengan menyebutnya 'putera Indonesia'. Di satu sisi, pemikiran Soekardjo Wirjopranoto dianggap maju karena ingin menempatkan semua warga negara memiliki kesempatan yang sama untuk menjadi Presiden terlepas dari agama yang dianutnya. Tetapi di sisi lain, keinginan tersebut belum ditujukan untuk'perempuan Indonesia'. Dengan kata lain, tampaknya Soekardjo Wirjopranoto sendiri masih belum memasukkan perempuan sebagai pihak yang pantas untuk menjadi Presiden meskipun tinggi budinya, pandai, atau giat sekalipun. ${ }^{53}$ Dengan kata lain, pemikiran Soekardjo tersebut mungkin dipengaruhi oleh adanya keinginan untuk hanya menempatkan laki-laki saja sebagai Presiden.

Adanya pengecualian terhadap jabatan Presiden hanya terbuka untuk orang Indonesia asli pada waktu penyusunan UUD oleh BPUPKI diakui oleh Saafroedin Bahar. Dalam tulisannya Saafroedin Bahar menjelaskan sebagai berikut: ${ }^{54}$

"Berbeda dengan diskriminasi ras dan etnik yang dianut oleh perundang-undangan Hindia Belanda, dalam pasal 27 ayat 1 rancangan Undang-Undang Dasar ditetapkan bahwa setiap penduduk

\footnotetext{
so Usep Ranawidjaja, Hukum Tata Negara Indonesia Dasar-dasarnya, Cetakan ke-2, Jakarta: Ghalia Indonesia, 1982, hlm. 100.

51 Hernadi Affandi, “Penerapan ..., Op.cit., hlm. 301.

52 Ibid.

53 Ibid.

54 Saafroedin Bahar dan Nannie Hudawati, Op.cit., hlm. xxxvii.
} 
bersamaan kedudukannya dalam hukum dan pemerintahan dan wajib mendukung hukum dan pemerintahan itu dengan tidak ada kecualinya. Satu-satunya pengecualian terhadap asas persamaan kedudukan penduduk ini adalah bahwa Presiden ialah orang Indonesia asli."

Berdasarkan uraian di atas dapat diketahui bahwa rumusan Pasal 27 ayat (1) dapat disimpulkan bahwa pasal tersebut lebih ditekankan kepada kedudukan warga negara di depan hukum dan pemerintahan dalam suatu negara yang berasaskan kekeluargaan dan bukan dalam negara yang berasaskan individualisme. Warga negara bersamaan kedudukan di depan hukum dan pemerintahan artinya bersamasama di depan hukum dan pemerintahan sebagai suatu keluarga dan tidak terpisah atau terpencar-pencar secara sendiri-sendiri, sehingga tidak ada kelas-kelas di antara warga negara. ${ }^{55}$

Apabila dikaitkan lebih lanjut dengan pandangan Soekardjo Wirjopranoto di atas bahwa rumusan Pasal 27 adalah dalam rangka pengakuan hak yang sama dari setiap warga negara oleh hukum dan negara. Dalam hal ini, warga negara tidak akan dikelas-kelas atau dikelompokkan dalam kelas-kelas seperti ke dalam kelas 1 atau kelas 2 dan seterusnya. Sebagai konsekuensi pengakuan yang sama terhadap warga negara adalah semua warga negara mempunyai hak yang sama untuk memperoleh kedudukan atau jabatan tertentu, khususnya jabatan Presiden. Pandangan Soekardjo Wirjopranoto khusus mengenai jabatan Presiden karena yang dibahas adalah materi muatan UUD.

Namun demikian, pandangan tersebut saat ini tentu tidak cukup, sehingga harus diperluas untuk semua jabatan dan bukan hanya untuk jabatan Presiden. Dalam konteks kekinian, rumusan bersamaan kedudukan dalam pemerintahan harus diartikan untuk semua jabatan seperti di jajaran eksekutif, legislatif, yudikatif, maupun jabatan lain baik di pusat maupun daerah. Artinya, bahwa setiap warga negara yang memenuhi syarat harus dibuka peluang dan kesempatannya untuk memperoleh, memegang, menduduki jabatan, sehingga semua warga negara memiliki hak dan kesempatan yang sama untuk mengelola negara sepanjang memenuhi persyaratan yang bersifat objektif. Dengan kata lain, bersamaan kedudukan di dalam pemerintahan dalam alam Indonesia merdeka sudah benarbenar terbuka karena semua warga negara sudah bersamaan kedudukannya di dalam hukum.

55 Hernadi Affandi, “Penerapan ..., Op.cit., hlm. 302. 


\section{E. Penutup}

Perbedaan pandangan dalam memaknai rumusan Pasal 27 ayat (1) UUD 1945 tidak terlalu mendapatkan jawaban memuaskan dari sejarah perumusan pasal tersebut dalam sidang BPUPKI dan PPKI. Oleh karena itu, amat wajar ketika masih sering terjadi perbedaan penafsiran terutama dalam menafsirkan makna 'bersamaan' kedudukan di dalam hukum dan pemerintahan. Sebagai konsekuensinya, terdapat pandangan yang menganggap bahwa UUD 1945 mengandung prinsip PKDH, sedangkan pendapat lain menganggap justru tidak mengandung prinsip PKDH tersebut. Ketiadaan pengaturan Prinsip PKDH di dalam UUD 1945 secara eksplisit menurut Penulis merupakan salah satu kelemahan yang dimiliki oleh UUD 1945.

Pengertian bersamaan kedudukan di dalam hukum dan pemerintahan harus dimaknai bahwa dalam konteks Pasal 27 ayat (1) semua warga negara tidak ada perbedaan yang disebabkan oleh perbedaan golongan penduduk seperti masa Hindia Belanda. Dalam hal ini, penempatan segala warga negara dalam kedudukan yang sama di dalam hukum adalah untuk menjamin keadilan bagi semua warga negara tanpa kecuali. Pengakuan tersebut akan membawa konsekuensi adanya kesempatan yang sama bagi semua warga negara untuk turut serta dalam pemerintahan. Adanya pengakuan dan jaminan atas semua warga negara dalam kedudukan yang sama merupakan konsekuensi dipilihnya sifat kekeluargaan dalam penyelenggaraan negara.

Perwujudan hubungan antara bersamaan kedudukan di dalam hukum dengan bersamaan kedudukkan di dalam pemerintahan adalah semua warga negara harus dianggap memiliki hak yang sama untuk memperoleh atau menduduki jabatan termasuk menjadi Presiden sepanjang memenuhi segala persyaratan yang sudah ditentukan. Dengan demikian, terdapat hubungan yang erat antara menempatkan seluruh warga negara ke dalam kelas yang sama dengan kesempatan setiap warga negara untuk menduduki semua jabatan. Setiap warga negara memiliki hak untuk turut-serta dalam pemerintahan termasuk untuk mendapatkan kesempatan dalam memperoleh dan menjadi pejabat dalam pemerintahan. Sebagai konsekuensinya, setiap warga negara memiliki hak dan kesempatan yang sama dalam memperoleh setiap jabatan yang tersedia secara adil.

\section{Daftar Pustaka \\ Buku}

Ali Abdurahman (eds), Satu Dasa Warsa Perubahan UUD 1945, Pusat Studi Kebijakan Negara (PSKN) Fakultas Hukum Universitas Padjadjaran, Bandung, 2012.

B. Arief Sidharta, Filsafat IImu Hukum, Laboratorium Hukum Fakultas Hukum Universitas Katolik Parahyangan, Bandung, 2005. 
Bagir Manan, Hukum Kewarganegaraan Indonesia Dalam UU No. 18 Tahun 2006, Cetakan ke-1, FH UII Press, Yogyakarta, 2009. , Membedah UUD 1945, UB Press, Malang, 2012.

Lev, Daniel S., Hukum dan Politik di Indonesia Kesinambungan dan Perubahan, buku diterjemahkan oleh Nirwono dan A.E. Prijono, Cetakan ke-3, Jakarta: LP3ES, 2013.

Muhammad Hatta, Menuju Gerbang Kemerdekaan Untuk Negeriku Sebuah Otobiografi, buku 3, Cetakan ke-7, PT. Kompas Media Nusantara, Jakarta, 2016. (et.al.), Uraian Pancasila, Mutiara, Jakarta, 1978.

Saafroedin Bahar dan Nannie Hudawati (eds), Risalah Sidang Badan Penyelidik Usaha-usaha Persiapan Kemerdekaan Indonesia (BPUPKI)-Panitia Persiapan Kemerdekaan Indonesia (PPKI), Edisi ke-IV, Cetakan ke-1, Sekretariat Negara Republik Indonesia, Jakarta, 1998.

Sekretariat Jenderal Majelis Permusyawaratan Rakyar Republik Indonesia, Panduan Pemasyarakatan Undang-Undang Dasar Negara Republik Indonesia Tahun 1945, Cetakan ke-2, Sekretariat Jenderal MPR, Jakarta, 2006.

Sri Soemantri, Prosedur dan Sistem Perubahan Konstitusi, Edisi ke-2, Cetakan ke-1, PT Alumni, Bandung, 2006.

Susi Dwi Harijanti (eds), Negara Hukum yang Berkeadilan: Kumpulan Pemikiran Dalam Rangka Purnabakti Prof. Dr. H. Bagir Manan, S.H., MCL., Rosda dan PSKNFH Unpad, Bandung, 2011.

Sutandyo Wignjosoebroto, Dari Hukum Kolonial ke Hukum Nasional Dinamika Sosial-Politik dalam Perkembangan Hukum di Indonesia, Cetakan ke-1, PT RajaGrafindo Persada, Jakarta, 1994.

Usep Ranawidjaja, Hukum Tata Negara Indonesia Dasar-dasarnya, Cetakan ke-2, Ghalia Indonesia, Jakarta, 1982.

Utrecht E., dan Moh. Saleh Djindang, Pengantar Dalam Hukum Indonesia, Cetakan ke-11, PT Ikhtiar Putra, Jakarta, 1989.

W.J.S. Poerwadarminta, Kamus Umum Bahasa Indonesia, Pradnja Paramita, Jakarta, 1982.

\section{Dokumen Lain}

Hernadi Affandi, "Penerapan Prinsip Persamaan Kedudukan di Depan Hukum Terhadap Hak Warga Negara Untuk Turut-Serta Dalam Pemerintahan Berdasarkan Undang-Undang Dasar 1945", Disertasi, Program Studi Doktor Ilmu Hukum Fakultas Hukum Universitas Padjadjaran, Bandung, 2013.

\section{Dokumen Hukum}

Undang-Undang Dasar Negara Republik Indonesia Tahun 1945.

Rancangan Undang-Undang Dasar Negara Republik Indonesia. 